\title{
PEMAAFAN DAN ASPEK KOGNITIF DARI STRES PADA MAHASISWI JURUSAN KEBIDANAN TINGKAT DUA
}

\author{
Amalia Rahmandani \\ Fakultas Psikologi Universitas Diponegoro \\ Jl. Prof Soedharto SH Tembalang Semarang 50275 \\ a.rahmandani@live.undip.ac.id
}

\begin{abstract}
Forgiveness is considered as emotion-focused coping, whereas cognition is one aspect that is affected when someone is in a stressful situation. This study aims to examine the relationship between forgiveness with the cognitive aspect of stress. The subjects were 77 second degree students of midwifery. Data were collected using the Forgiveness Psychological Scale (43 item, $\alpha=.924$ ) and Cognitive Aspect of Stress Scale (22 item, $\alpha$ $=.886$ ). The results showed a significant positive relationship between forgiveness with the cognitive aspect of stress $\left(\mathrm{r}_{\mathrm{xy}}=.504 ; \mathrm{p}<.001\right)$. The higher the level of forgiveness, the better of cognitive activities in stressful situation, and conversely. Forgiveness contributed $25.4 \%$ to the prediction of cognitive aspect of stress.
\end{abstract}

Keywords: forgiveness, cognitive aspect of stress, sophomore, midwifery students

\begin{abstract}
Abstrak
Pemaafan disebut sebagai salah satu strategi penanggulangan masalah yang berfokus pada emosi, sedangkan kognisi merupakan salah satu aspek yang dipengaruhi saat seseorang sedang berada dalam situasi penuh tekanan. Penelitian ini bertujuan untuk mengkaji hubungan antara pemaafan dengan aspek kognitif dari stres. Subjek penelitian ini adalah 77 orang mahasiswi jurusan kebidanan tingkat dua. Data dikumpulkan menggunakan Skala Psikologi tentang Pemaafan (43 aitem, $\alpha=0,924)$ dan Skala Aspek Kognitif dari Stres (22 aitem, $\alpha=0,886$ ). Hasil penelitian menunjukkan adanya hubungan positif yang signifikan antara pemaafan dengan aspek kognitif dari stres $\left(\mathrm{r}_{\mathrm{xy}}=0,504 ; \mathrm{p}<0,001\right)$. Semakin tinggi tingkat pemaafan mahasiswi, semakin baik aktivitas kognitif dalam situasi penuh tekanan, dan sebaliknya. Pemaafan memberikan sumbangan prediksi sebesar $25,4 \%$ pada aspek kognitif dari stres.
\end{abstract}

Kata kunci: pemaafan, aspek kognitif dari stres, mahasiswi kebidanan tingkat dua

\section{PENDAHULUAN}

Stres nampaknya memiliki dampak yang cukup luas bagi kehidupan seseorang. Adanya masa transisi sebagai akibat bertambahnya usia pada periode perkembangan seseorang merupakan faktor tersendiri yang mampu memunculkan stres pada tingkatan tertentu. Selain memenuhi harapan sosial pada periode perkembangan yang dilaluinya (normative transition), setiap orang juga akan menghadapi tuntutan berbagai faktor psikososial yang bersifat insidental terlepas dari periode manakah saat ini dia berada (non- normative events). Selanjutnya, hambatan terhadap penguasaan tugas-tugas perkembangan pada berbagai periode sepanjang hidup dapat dianggap sebagai bahaya potensial (Hurlock, 2003).

Mahasiswa tingkat pertama selain harus menghadapi situasi stresful dan beradaptasi dengan hal berkenaan tugasnya dalam menempuh pendidikan, ia juga dihadapkan pada situasi yang menuntut pemenuhan tugas-tugas perkembangan pada remaja akhir memasuki masa dewasa. Tidak menutup kemungkinan pula terjadi peristiwa non-normatif yang tidak berlaku 
umum pada semua orang di usianya. Sebuah penelitian menentukan sumbersumber stres utama di antara mahasiswa menghasilkan distribusi respon bahwa 38\% dari stresor adalah intrapersonal, $28 \%$ lingkungan, $19 \%$ interpersonal, dan $15 \%$ akademik (Ross, Niebling, \& Heckert, 1999).

Selanjutnya, bahaya potensial yang mungkin muncul pada remaja adalah adanya dampak psikologis jangka panjang sebagai akibat situasi stresful seperti penolakan teman sebaya (Lev-Wiesel, Nuttman-Shwartz, \& Sternberg, 2006), stres keluarga akibat praktik pengasuhan (Vassi, Veltsista, \& Bakoula, 2009) atau stres traumatik tertentu dalam keluarga (Matsakis, 2004).

Penelitian yang lain menjelaskan dampak stres pada masa kanak dan remaja terhadap lepasnya ikatan dalam hubungan sosial/ social disengagement (Caldwell, Rudolph, Troop-Gordon, \& Kim, 2004), menurunnya performa akademik dan prestasi (Andrews \& Wilding, 2004), terjadinya stres dalam kehidupan marital di masa dewasa (Umberson, Williams, Powers, Liu, \& Needham, 2005), mengalami peningkatan stres dan kurangnya kendali terhadap pekerjaan pada masa dewasa (Fitzgerald, Brown, Sonnega, \& Ewart, 2004), atau munculnya berbagai masalah kesehatan mental/ psikopatologi pada masa dewasa (Vassi, Veltsista, \& Bakoula, 2009).

Stres didefinisikan melalui tiga cara, yaitu (1) stres sebagai stresor yang mengacu pada stimulus eksternal, (2) stres sebagai strain atau ketegangan berupa reaksi internal organisme akibat stresor, dan (3) stres sebagai transaksi antara stresor dan individu yang saling mempengaruhi dan membu-tuhkan penyesuaian berkesinambungan (Lazarus, dalam Sarafino \& Smith, 2011; Aldwin, 2007). Lebih lanjut, Lazarus dan Folkman (dalam Sarafino \& Smith, 2011; Carver, 2007) mendefinisikan stres sebagai keadaan di mana terjadinya transaksi menyebabkan seseorang merasakan ketidak-sesuaian antara tuntutan fisik atau psikologis dari situasi, dengan sumber daya sistem biologis, psikologis, dan sosial yang dimilikinya. Aldwin (2007) menambahkan, baik berlebihan atau tidak, pengalaman yang dihasilkan dari transaksi individu dengan lingkungan telah berdampak pada pembangkitan distres secara psikologis atau fisiologis.

Salah satu hal penting yang perlu diingat adalah bahwa ketidaksesuaian antara tuntutan dan sumber daya yang dimiliki dapat nyata terjadi atau hanya diyakini ada. Stres seringkali dihasilkan dari persepsi yang tidak akurat mengenai ketimpangan antara tuntutan lingkungan dengan sumbersumber yang aktual dimiliki. Stres tergantung pada bagaimana seseorang melihatnya. Sanderson (2013) menyebutkan bahwa stres selain mengacu pada pengalaman peristiwa besar, juga mengacu pada persepsi bahwa seseorang tidak memiliki sumber daya yang cukup untuk mengatasi kejadian tersebut.

Uraian di atas menjelaskan bahwa stres tidak hanya dipandang sebagai stimulus dan respon yang melibatkan berbagai perubahan, tetapi juga dipandang sebagai proses dimana seseorang adalah agen yang aktif dan dapat mempengaruhi dampak dari stresor melalui strategi tingkah laku, kognitif, dan emosional (Sarafino \& Smith, 2011).

Dengan demikian, stres melibatkan adanya penilaian individu tentang interaksinya dengan lingkungan, kesesuaian antara sumber daya yang dimiliki untuk mengatasi tuntutan situasi, dan pengaruh ketidaksesuaian yang dirasakan terhadap munculnya pembangkitan baik secara 
psikologis maupun fisiologis dalam batas tertentu.

Ketidaksesuaian antara sumber daya individu dalam menanggulangi stres, selanjutnya dapat dirasakan sebagai suatu bentuk pelanggaran atas hak-hak pribadi sehingga seseorang berhak untuk merasa marah, benci, bahkan dendam, dan merasa pantas untuk disebut korban.

Stres sebagai akibat peristiwa dalam kehidupan tersebut mencemari harapan dan asumsi mengenai bagaimana mereka, orang lain, atau dunia seharusnya. Thompson dkk (dikutip oleh Snyder \& Lopez, 2007) menyebutkan bahwa objek dari pelanggaran nampaknya tidak secara eksklusif terbatas pada hubungan dengan orang lain, melainkan juga pelanggaran yang dilakukan oleh diri sendiri, bahkan situasi (seperti penyakit atau bencana alam). Sebagaimana stres, maka kondisi tersebut memunculkan berbagai respon negatif, seperti pikiran negatif (misal, "Semua ini telah mengacaukan hidupku"), perasaan negatif (misal, marah), atau perilaku (misal, pembalasan dendam) (Thompson dkk, 2005).

Melihat dampak ketidaksesuaian antara tuntutan eksternal dan sumberdaya yang dimiliki terhadap munculnya berbagai permasalahan dalam kehidupan, maka penting mengidentifikasi bagaimana stres dipertahankan.

Kognisi nampaknya memberikan sumbangan yang penting bagi bertahannya stres, mengingat adanya hubungan dua arah antara kognisi dan stres yang dijelaskan dalam kerja fungsi eksekutif, yaitu seperangkat kemampuan kognitif yang mengatur dan mengarahkan perilaku yang berkelanjutan (Suchy dalam Sarafino \& Smith, 2011). Fungsi kognitif eksekutif yang lebih baik secara nyata dapat membantu seseorang mengelola tuntutan situasi stres. Namun stres sementara juga mampu mengakibatkan kelelahan bagi sumber daya kognitif sehingga muncul kesulitan dalam hal konsentrasi, memori, pemecahan masalah, dan kendali impuls selama pengalaman stres. Stres bahkan dapat memunculkan pikiran negatif yang selanjutnya memungkinkannya bertahan lebih lama bahkan merugikan (Sarafino \& Smith, 2011).

Lebih jauh, dampak stres terhadap fungsi kognitif tersebut disebut secara eksplisit sebagai aspek kognitif dari stres (Sanderson, 2013; Sarafino \& Smith, 2011; Morrison \& Bennett, 2009), yang meliputi beberapa indikator yaitu memori, atensi dan kemampuan konsentrasi, sifat pemikiran, pengambilan keputusan/ pemecahan masalah, dan kendali impuls.

Salah satu trait yang mengurangi dampak situasi penuh tekanan (stressful) atau pelanggaran adalah dengan menjadi pemaaf atau bersedia memaafkan. Pemaafan merupakan salah satu dari berbagai kajian dalam psikologi positif, yaitu pendekatan ilmiah dan terapan untuk mengungkap berbagai kekuatan seseorang dan mendorong fungsi positif mereka (Snyder \& Lopez, 2007). Memaafkan bahkan dianggap sebagai salah satu penanggulangan masalah yang berfokus pada emosi yang dapat mengurangi risiko kesehatan dan meningkatkan resiliensi sehat (Worthington \& Scherer, 2004).

Pengertian pemaafan atau kesediaan untuk memaafkan yang disarikan dari berbagai sumber adalah upaya yang dilakukan dengan melibatkan perubahan baik kognitif, afektif, maupun perilaku, dengan melepaskan hak sebagai korban akibat terjadi pelanggaran, ditunjukkan dengan berkurangnya perasaan marah/ benci/ dendam, penilaian negatif, keinginan untuk bersikap acuh tak acuh, menghindari orang yang telah melakukan pelanggaran, dan 
keinginan untuk menyakiti atau membalas dendam terhadap individu itu, dan bahkan meningkatkan perasaan belas kasih, kemurahan hati, dan bahkan cinta, penilaian positif, keinginan untuk bertindak secara positif terhadap orang yang telah melakukan pelanggaran (Enright, 2002; Thompson dkk., 2005; McCullough dalam Snyder \& Lopez, 2007; Tangney, Fee, Reinsmith, Boone, \& Lee dalam Snyder \& Lopez, 2007).

Ketidaksediaan untuk memaafkan terbukti menimbulkan berbagai masalah dalam kehidupan. Enright (2002) menyebutkan bahwa korban mungkin melakukan berbagai mekanisme pertahanan diri yang tidak membantu dan semakin melemahkan sumber daya dalam dirinya seperti munculnya berbagai emosi negatif, distorsi kognitif, kondisi kesehatan yang menurun, maupun perilaku yang tidak adaptif. Sebaliknya, kesediaan untuk memaafkan membuka kesempatan bagi setiap orang untuk jujur mengakui perasaan-perasaan menyakitkan yang dialami, memiliki pandangan yang lebih baik, dan merasa terbebas dari penjara emosional (Enright, 2002).

Dengan mempertimbangkan pemaafan sebagai salah satu penanggulangan masalah terhadap pelanggaran dalam kehidupan, dan menjadikannya sifat/ pembawaan dalam menanggulangi menghadapi setiap stresor yang dialami, maka pemaafan dapat menjadi sumber daya bagi individu. Pemaafan diharapkan mampu mengurangi risiko penurunan aktivitas kognitif akibat tuntutan situasi, bahkan mengotimalkan aktivitas kognitif saat menghadapi stimulus/ problem yang membutuhkan penyelesaian.

Berdasarkan uraian di atas, penelitian ini bertujuan untuk menguji hubungan antara pemaafan (kesediaan memaafkan) dengan aspek kognitif dari stres pada mahasiswa serta mengetahui besaran prediksinya.

Hipotesis dari penelitian ini adalah terdapat hubungan positif antara pemaafan dengan aspek kognitif dari stres pada mahasiswa. Semakin tinggi tingkat pemaafan yang dimiliki, maka semakin baik aktivitas kognitif saat menghadapi stres. Begitu pula sebaliknya, semakin rendah tingkat pemaafan yang dimiliki, maka semakin buruk aktivitas kognitif saat menghadapi stres.

\section{METODE}

Penelitian ini merupakan studi populasi yang melibatkan 77 mahasiswi tingkat dua Program D-III Akademi Kebidanan Politeknik Kesehatan Kemenkes Semarang. Seluruh subjek adalah perempuan yang berusia $18-20$ tahun.

Data dikumpulkan menggunakan Skala Pemaafan (43 aitem; $r_{i x}$ antara 0,301 hingga 0,618; $\alpha=0,924)$ dan Skala Aspek Kognitif dari Stres (22 aitem; $r_{i x}$ antara $0,308$ hingga 0,$680 ; \alpha=0,886)$. Kedua skala menggunakan skala Likert, terdiri dari empat kategori respon, yaitu sangat tidak sesuai (STS), tidak sesuai (TS), sesuai (S), dan sangat sesuai (SS). Skor pada aitem favorable, secara berurutan STS, TS, S, dan SS adalah 1, 2, 3, dan, 4. Sedangkan skor pada aitem unfavorable sesuai dengan urutan respon di atas adalah 4,3,2, dan 1. Kedua skala telah diujicobakan kepada 36 mahasiswi tingkat dua Program D-IV Akademi Kebidanan Politeknik Kesehatan Kemenkes Semarang.

Skala pemaafan bertujuan untuk mengungkap seberapa tinggi tingkat pemaafan (kesediaan memaafkan) pada subjek. Aitem-aitem dalam skala ini disusun berdasarkan aspek-aspek pemaafan menurut Thompson dkk (dalam Snyder 
dan Lopez, 2007) meliputi pemaafan terhadap orang lain, diri sendiri, maupun situasi. Penyusunan aitem pada masingmasing aspek akan mempertimbangkan perubahan baik secara kognitif, afektif, maupun perilaku; serta berkurangnya halhal negatif dan meningkatnya hal-hal yang positif (Enright, 2002). Skor yang tinggi pada skala ini menunjukkan kecenderungan lebih besar untuk memaafkan diri sendiri, orang lain, maupun situasi, terlihat dari berkurangnya pemikiran, perasaan, maupun perilaku yang negatif dan meningkatnya pemikiran perasaan, mapun perilaku yang positif. Contoh aitem favorable berkurangnya perilaku negatif pada aspek pemaafan terhadap diri sendiri adalah "Setelah menarik diri beberapa saat akibat masalah yang saya timbulkan, saya perlahan kembali beraktivitas seperti biasa". Contoh aitem favorable meningkatnya perasaan positif pada aspek pemaafan terhadap orang lain adalah "Saya merasa berterima kasih kepada orang yang pernah menyakiti saya karena telah mengajarkan banyak tentang kehidupan". Contoh aitem unfavorable meningkatnya pemikiran positif pada aspek pemaafan terhadap situasi adalah "Saya memandang dunia seolah berlaku tidak adil karena musibah yang terjadi".

Skala aspek kognitif dari stres bertujuan untuk mengungkap seberapa baik fungsi aspek kognitif saat menghadapi stres pada subjek. Aitem-aitem dalam skala ini disusun berdasarkan sub-aspek yang telah dirumuskan dari teori stres yang berfokus pada aspek kognitif, meliputi (1) memori, (2) atensi/ konsentrasi, (3) sifat pemikiran, (4) pengambilan keputusan (pemecahan masalah), dan (5) kendali impuls (Sanderson, 2013; Sarafino \& Smith, 2011; Suchy dalam Sarafino \& Smith, 2011; Cohen dkk., dalam Morrison \& Bennett, 2009). Skor yang tinggi pada skala ini menunjukkan kecenderungan bahwa aktivitas kognitif dapat dilakukan dengan baik dan terhindar dari gangguan pada subsub aspek tersebut saat berada dalam situasi penuh tekanan. Contoh aitem favorable pada sub-aspek atensi adalah "Saya dapat mendengarkan setiap instruksi tugas baru secara seksama hingga selesai". Contoh aitem unfavorable pada sub-aspek kendali impuls adalah "Saat merasa tertekan dengan situasi, saya lupa memikirkan risiko akibat tindakan yang saya ambil".

Penelitian ini dilakukan dengan rancangan studi korelasional dengan metode statistik analisis regresi sederhana. Data yang diperoleh selanjutnya diolah menggunakan program komputer Statistic Packages for Social Science (SPSS) versi 16.0.

\section{HASIL DAN PEMBAHASAN}

Hasil penghitungan statistik setelah memenuhi uji asumsi normalitas dan linieritas distribusi penelitian menunjukkan bahwa koefisien korelasi antara pemaafan dengan aspek kognitif dari stres $\left(r_{\mathrm{xy}}\right)$ adalah 0,504 dengan tingkat signifikansi 0.000 ( $\mathrm{p}<0,05)$. Koefisien korelasi tersebut mengindikasi adanya hubungan antara variabel pemaafan dengan aspek kognitif dari stres. Koefisien korelasi bernilai positif yang menunjukkan arah hubungan yang positif diantara kedua variabel, artinya semakin tinggi tingkat pemaafan yang dimiliki, maka semakin baik pula aktivitas kognitif saat menghadapi stres. Begitu pula sebaliknya, semakin rendah tingkat pemaafan yang dimiliki, maka semakin buruk pula aktivitas kognitif saat menghadapi stres. Hasil analisis regresi sederhana menunjukkan bahwa hipotesis yang diajukan peneliti dapat diterima.

Persamaan garis regresi untuk hubungan antara pemaafan dengan aspek kognitif dari stres adalah sebagai berikut : 
$\mathrm{y}=24,800+0,275 \mathrm{x}$. Persamaan garis tersebut menandakan tiap penambahan satu nilai pada variabel pemaafan, maka diikuti dengan penambahan nilai variabel aspek kognitif dari stres sebesar 0,275.

Nilai koefisien determinasi $\left(\mathrm{R}^{2}\right)$ sebesar 0,254, artinya pemaafan memberi sumbangan efektif sebesar $25,4 \%$ terhadap aspek kognitif dari stres. Sedangkan sisanya $74,6 \%$ ditentukan oleh faktor lain yang tidak diungkap dalam penelitian ini. Perkiraan kesalahan sebesar 5,415 termasuk dalam jumlah kecil. Jadi bisa diartikan secara keseluruhan model regresi tepat dalam memprediksi pengaruh variabel pemaafan terhadap aspek kognitif dari stres.

Orang yang tidak bersedia memaafkan memiliki implikasi yang jelas. Hal yang mungkin muncul adalah penolakan secara terang-terangan untuk memaafkan dan ditunjukkan dalam wujud perilaku sebagai manifestasi atas perasaan dan pikiran negatifnya. Namun sebagian orang lain yang tidak memaafkan menyimpan pengalaman-nya dan melakukan berbagai mekanisme pertahanan diri yang tidak membantu bahkan semakin melemahkan sumber daya dalam dirinya seperti munculnya berbagai emosi negatif, distorsi kognitif, kondisi kesehatan yang menurun, maupun perilaku yang tidak adaptif (Enright, 2002).

Pemaafan dipertimbangkan sebagai salah satu strategi penanggulangan yang berfokus pada emosi yang dapat mengurangi risiko masalah kesehatan dan meningkatkan resiliensi sehat (Worthington \& Scherer, 2004). Strategi penanggulangan yang berfokus pada emosi melibatkan pengelolaan emosi dan upaya mempertahankan keseimbangan emosional (Ogden, 2007). Ini berarti bahwa seseorang yang memaafkan akan mengatur respon emosional terhadap peristiwa buruk akibat kekacauan yang ditimbulkan sendiri, pelanggaran yang dilakukan oleh orang lain, atau akibat situasi yang tidak dapat dikendalikan, sehingga dapat merasakan pengurangan emosi, pikiran, serta perilaku negatif, dan selanjutnya meningkatkan kualitas positif yang ditujukan bagi diri sendiri, orang lain, dan situasi.

Definisi mengenai pemaafan nampaknya tidak sesederhana sebagaimana yang dipahami oleh kebanyakan orang. Memaafkan bukanlah sekedar menerima apa yang terjadi, menghentikan amarah, netral di hadapan orang lain, membuat diri sendiri merasa lebih nyaman. Memaafkan juga didefinisikan secara berbeda dengan memastikan ada yang salah, membebaskan pertanggungjawaban, welas asih, mengampuni, memaklumi, melupakan, membebaskan tuduhan, maupun rekonsiliasi (Enright, 2002; dalam Afif 2015).

Pemaafan yang tulus dan benar juga akan mengandung implikasi yang berbeda dengan pemaafan yang palsu atau berpurapura, baik disadari maupun tidak disadari. Inilah sebabnya mengapa isu mengenai mekanisme pertahanan diri muncul dalam proses memaafkan, selain alasan bahwa untuk menjalani proses memaafkan itu sendiri bukan suatu hal yang mudah. Seseorang yang sudah memulai proses memaafkan sangat mungkin sekali kembali memulai prosesnya dari awal atau bahkan menjadi tidak bersedia memaafkan karena merasa belum benar-benar siap (Enright, 2002).

Telah dijelaskan diatas bahwa pemaafan dipertimbangkan sebagai salah satu strategi penanggulangan yang berfokus pada emosi. Pengelolaan emosi sangat banyak memberikan manfaat bagi kinerja fungsi kognitif pada saat menghadapi stres. Strategi pengelolaan emosi akan berdampak pada konsekuensi kognitif yang 
berbeda (Suri, Sheppes, \& Gross, 2013). Tentunya, manfaat dari pemaafan akan menjadi optimal saat melakukannya dengan benar-benar tulus.

Emosi memberikan pengaruh pada memori dalam berbagai tahap (Murray, Holland, \& Kensinger, 2013), yaitu pertama, emosi mempengaruhi cara informasi pertama kali diproses dan ditransformasikan ke dalam ingatan (tahap encoding). Hal ini akan berkaitan pula dengan atensi/ perhatian yang akan dibahas pada paragraf selanjutnya. Kedua, emosi mempengaruhi cara saat informasi dimantapkan (tahap konsolidasi), dan ketiga, emosi mempengaruhi cara bagaimana ingatan dimunculkan kembali (tahap retrieval). Seseorang dapat mengalami lupa yang temporer saat dihadapkan pada situasi stresful atau memanggil ingatan yang keliru. Memaafkan dapat memberikan kesempatan bagi seseorang untuk menurunkan tingkat distres, meningkatkan relaksasi, sehingga membuat aktivitas kognitif berfungsi secara lebih luwes, mengingat informasi yang tepat saat dibutuhkan.

Tahap satu di atas yaitu tahap dimana informasi pertama kali diproses dan ditransformasikan ke dalam ingatan sangat berkaitan dengan atensi (perhatian). Atensi memiliki dua fungsi utama dalam kehidupan sehari-hari, yaitu (1) dalam memilih dan memproses informasi yang relevan dengan tugas-tugas pada saat itu, dan (2) memproses informasi yang relevan, potensial, dan baru (Allport, dalam Yiend, Barnicot, \& Koster, 2013). Kegagalan dalam kemampuan mengatur perhatian secara adaptif selama pemrosesan informasi yang bersifat emosional dapat menjadikan kerentanan terhadap stres dan perkembangan gangguan emosional, sebaliknya kemampuan untuk mengubah secara fleksibel antara stimulus yang berbeda di lingkungan penting untuk menangani pikiran yang mendistraksi dan penting bagi keberfungsian yang sehat dan daya lenting (Yiend, Barnicot, \& Koster, 2013).

Selanjutnya, suasana hati dan proses emosi lain mempengaruhi pengambilan keputusan dalam tiga cara yang berbeda (Raghunatan \& Pham, dalam Västfjäll \& Slovic, 2013). Pertama, suasana hati pada saat pengambilan keputusan dapat mempengaruhi sisi pemikiran seseorang, contohnya orang yang sedang dalam suasana hati yang positif akan lebih mudah berfikir positif dan mengingat kembali ingatan yang positif. Kedua, suasana hati yang positif dan negatif dapat mempengaruhi kapabilitas pemrosesan, contohnya seseorang yang sedang merasa bahagia seringkali cenderung kurang mengelaborasi dan sistematis dalam pengolahan informasi dibandingkan orang dalam suasana hati yang buruk. Ketiga, suasana hati pada saat itu dapat mempengaruhi motif pengambilan tindakan, contohnya seseorang yang sedang merasa bahagia dapat menghindari peristiwa yang negatif sebagai upaya untuk mempertahankan keadaan suasana hati mereka yang positif.

Selanjutnya adalah pengaruh emosi terhadap kendali impuls. Bukti menunjukkan bahwa keadaan emosional dapat mengurangi atau meningkatkan kendali diri tergantung pada orang yang mengalami dan situasinya (Schmeichel \& Inzlicht, 2013). Mengetahui tentang bagaimana dan kapan perlu mengelola kecenderungan perilaku impulsif dan dapat mengelolanya dengan sukses dapat meningkatkan fleksibilitas perilaku yang bermanfaat bagi diri dan lingkungan, berkontribusi bagi kesehatan fisik, kesejahteraan psikologis, umur panjang, pencapaian pekerjaan, kepuasan hubungan, beberapa dampak lain yang diharapkan 
(Vohs \& Baumeister, dalam Schmeichel \& Inzlicht, 2013).

Situasi stresful yang mungkin dialami remaja pada masa transisi memasuki perguruan tinggi dan memenuhi tuntutan pendidikan kebidanan pada tahun pertama perlu mendapatkan perhatian sehingga tidak menimbulkan dampak yang besar dan berkepanjangan bagi kehidupan ke depan. Masa remaja, khususnya remaja akhir, merupakan masa yang paling dekat dengan transisi menuju usia dewasa. Situasi perubahan yang bersifat normatif berupa tugas-tugas perkembangan yang menjadi harapan sosial, dan yang bersifat non-normatif berupa peristiwa kehidupan yang hanya dialami oleh sebagian kecil remaja merupakan situasi yang berhubungan erat dengan penanggulangan masalah selama menempuh pendidikan, baik yang bersifat teori maupun praktik pada akhir tahun pertama. Sebagaimana dijelaskan oleh Jones dan Johnston (2000) bahwa distres dari mahasiswa kebidanan tingkat pertama disebutkan memiliki derajat yang tinggi melebihi distres yang dilaporkan oleh kelompok profesional kesehatan lain.

Berdasarkan hasil penelitian ini, pemaafan dapat menjadi salah satu pilihan penanggulangan masalah yang berfokus pada emosi bagi subjek untuk mengoptimalkan aktivitas kognitif pada saat menghadapi situasi yang menekan. Fungsi kognitif eksekutif yang lebih baik secara nyata dapat membantu seseorang mengelola tuntutan situasi stres. Penilaian terhadap situasi yang menekan akan dirasakan sebagai tantangan yang mampu memberikan kontribusi bagi pengembangan pribadi.

Berikut adalah analisis tambahan mengenai deskripsi subjek penelitian:
Tabel 1.

Perbandingan Mean dan Standar Deviasi

\begin{tabular}{clcc}
\hline Variabel & \multicolumn{1}{c}{ Statistik } & Hipotetik & Empirik \\
\hline \multirow{3}{*}{ Pemaafan } & Skor Min & 43 & 102 \\
\cline { 2 - 4 } & Skor Maks & 172 & 155 \\
\cline { 2 - 4 } & Rerata (Mean) & 107,5 & 130,87 \\
\cline { 2 - 4 } & SD & 21,5 & 11,419 \\
\hline \multirow{2}{*}{$\begin{array}{c}\text { Aspek } \\
\text { Kognitif dari } \\
\text { Stres }\end{array}$} & Skor Min & 22 & 42 \\
\cline { 2 - 4 } & Skor Maks & 88 & 78 \\
\cline { 2 - 4 } & Rerata (Mean ) & 55 & 60,77 \\
\hline
\end{tabular}

Gambaran umum di atas menjelaskan bahwa skor terendah dari kelompok subjek dalam skala pemaafan adalah 102 dan skor tertinggi 155 , dengan rata-rata skor adalah 130,87 . Skor terendah dalam skala aspek kognitif dari stres adalah 42 dan skor tertinggi adalah 78, dengan rata-rata skor yaitu 60,77. Sedangkan kategorisasi subjek selanjutnya dibuat dengan menggunakan norma hipotetik.

Pembuatan kategorisasi digunakan untuk memberi pemaknaan pada skor yang telah didapatkan. Kategorisasi juga bertujuan untuk menempatkan individu ke dalam kelompok-kelompok yang terpisah secara berjenjang menurut suatu kontinum tertentu. Penelitian ini menggunakan lima kategorisasi yang terdiri dari sangat rendah, rendah, sedang, tinggi, dan sangat tinggi.

Adapun kategorisasi dan distribusi subjek penelitian variabel pemaafan dan aspek kognitif dari stres ditampilkan pada Tabel 2 dan Tabel 3.

Tabel 2.

Kategorisasi dan Distribusi Subjek Penelitian Variabel Pemaafan

\begin{tabular}{ccccc}
\hline $\begin{array}{c}\text { Sangat } \\
\text { Rendah }\end{array}$ & Rendah & Sedang & Tinggi & $\begin{array}{c}\text { Sangat } \\
\text { Tinggi }\end{array}$ \\
\hline $\mathrm{N}=0$ & $\mathrm{~N}=0$ & $\mathrm{~N}=11$ & $\mathrm{~N}=50$ & $\mathrm{~N}=16$ \\
\hline $0 \%$ & $0 \%$ & $14,29 \%$ & $64,94 \%$ & $20,78 \%$ \\
\hline 75,25 & \multicolumn{5}{c}{96,75} & 118,25 & 139,75
\end{tabular}


Tabel 3.

Kategorisasi dan Distribusi Subjek Penelitian Variabel Aspek Kognitif dari Stres

\begin{tabular}{ccccc}
\hline $\begin{array}{c}\text { Sangat } \\
\text { Rendah }\end{array}$ & Rendah & Sedang & Tinggi & $\begin{array}{c}\text { Sangat } \\
\text { Tinggi }\end{array}$ \\
\hline $\mathrm{N}=0$ & $\mathrm{~N}=1$ & $\mathrm{~N}=36$ & $\mathrm{~N}=35$ & $\mathrm{~N}=5$ \\
\hline $0 \%$ & $1,3 \%$ & $46,75 \%$ & $45,45 \%$ & $6,49 \%$ \\
\hline \multicolumn{6}{c}{38,5} & 49,5 & 60,5 & 71,5
\end{tabular}

Penelitian ini memberikan implikasi bagi individu dalam kelompok subjek maupun orang lain untuk mempertimbangkan pemaafan sebagai salah satu strategi dalam menanggulangi masalah yang berfokus pada emosi dengan cara mengatur respon emosional melalui pengelolaan perasaan, cara berfikir, dan tindakan yang membantu mengurangi komponen-komponen negatif serta meningkatkan konponen positif yang ditujukan baik bagi diri sendiri, orang lain, maupun situasi. Pemaafan nampak bukan suatu proses yang mudah, namun hal ini menyumbang bagi perbaikan aktivitas kognitif dalam menghadapi stres sehingga dapat lebih optimal dalam memanfaatkan ingatan, perhatian, penilaian, pengambilan keputusan, dan kendali impuls.

Praktisi psikologi dapat mempertimbangkan pemaafan sebagai salah satu alternatif intervensi positif untuk mengoptimalkan fungsi seseorang dalam menghadapi dan menyelesaikan permasalahan. Penelitian selanjutnya dapat mempertim-bangkan replikasi penelitian guna menyempurnakan alat ukur, memberikan pada populasi dengan jumlah sampel yang lebih banyak dan karakteristik yang bervariasi, melakukan uji komparasi untuk melihat perbedaan sumbangan pemaafan yang dapat diberikan.

\section{KESIMPULAN}

Berdasarkan hasil penelitian yang diperoleh, maka disimpulkan bahwa terdapat hubungan positif yang signifikan antara pemaafan dengan aspek kognitif dari stres pada populasi mahasiswi tingkat dua (semester 3 awal) Program D-III Akademi Kebidanan Politeknik Kesehatan Kemenkes Semarang. Semakin tinggi tingkat pemaafan yang dimiliki, maka semakin baik pula aktivitas kognitif saat menghadapi stres. Begitu pula sebaliknya, semakin rendah tingkat pemaafan yang dimiliki, maka semakin buruk pula aktivitas kognitif saat menghadapi stres. Pemaafan memberi sumbangan efektif sebesar 25,4\% terhadap aspek kognitif dari stres.

\section{DAFTAR PUSTAKA}

Afif, A. (2015). Pemaafan, rekonsiliasi, dan restorative justice. Diskursus perihal pelanggaran di masa lalu dan upaya-upaya melampauinya. Yogyakarta: Pustaka Pelajar.

Aldwin, C. M. (2007). Stress, coping, and development, An integrative perspective, 2nd edition. New York, NY: The Guilford Press.

Andrews, B., \& Wilding, J. M. (2004). The relation of depression and anxiety to life-stress and achievement in students. British Journal of Psychology, 95, 509-521.

Caldwell, M. S., Rudolph, K. D., TroopGordon, W., \& Kim, D. Y. (2004). Reciprocal influences among relational self-views, social disengagement, and peer stress during early adolescence. Child Development, 75 (4), 1140 - 1154.

Carver, C. S. (2007). Stress, coping, and health. Dalam H. S. Friedman \& R. C. Silver (Eds.), Foundation of health psychology. New York: Oxford University Press, Inc. 
Enright, R. D. (2002). Forgiveness is a choice, a step-by-step process for resolving anger and restoring hope. Washington, DC: American Psychological. Association.

Fitzgerald, S. T., Brown, K. M., Sonnega, J. R., \& Ewart, C. K. (2004). Early antecedents of adult work stress: Social-emotional competence and anger in adolescence. Journal of Behavioral Medicine, 28 (3), 223230 .

Hurlock, E. B. (2003). Psikologi perkembangan: suatu pendekatan sepanjang rentang kehidupan. Jakarta: Erlangga.

Jones, M. C., \& Johnston, D. W. (2000). Reducing distress in first level and student nurses: a review of the applied stress management literature. Journal of Advance Nursing, 32 (1), 66-74.

Lazarus, R. S. \& Folkman, S. (1984). Stress, appraisal, dan coping. New York: $\quad$ Springer Publishing Company, Inc.

Lev-Wiesel, R., Nuttman-Shwartz, O., \& Sternberg, R. (2006). Peer rejection during adolescence: Psychological long-term effects - a brief report. Journal of Loss and Trauma, 11, 131-142.

Matsakis, A. (2004). Trauma and its impact on families. Dalam D. R. Catherall (Ed.), Handbook of stress, trauma and the family. New York: Brunner-Routledge.

Morrison, V., \& Bennett, P. (2009). An introduction to health psychology, 2nd edition. England: Pearson Education.
Murray, B. D., Holland, A. C., \& Kensinger, E. A. (2013). Episodic memory and emotion. Dalam M. D. Robinson, E. R. Watkins, E. H. Jones (Eds.), Handbook of cognition and emotion. New York: The Guilford Press.

Ogden, J. (2007). Health psychology, A textbook, 4th edition. England: McGraw-Hill.

Ross, S. E., Niebling, B. C., \& Heckert, T. M. (1999). Sources of stress among college students. College Student Journal, 33, 312-317.

Sanderson, C. A. (2013). Health psychology, 2nd edition. USA: John Wiley \& Sons, Inc.

Sarafino, E. P., \& Smith, T. W. (2011). Health psychology: Biopsychosocial interactions, 7th edition. USA: John Wiley \& Sons, Inc.

Schmeichel, B.J., \& Inzlicht, M. (2013). Incidental and integral effects of emotions on self-control. Dalam M. D. Robinson, E. R. Watkins, E. H. Jones (Eds.), Handbook of cognition and emotion. New York: The Guilford Press.

Snyder, C. R., \& Lopez, S. J. (2007). Positive psychology, the scientific and practical explorations of human strengths. California: Sage Publications, Inc.

Suri, G., Sheppes, G., \& Gross, J. J. (2013). Emotion regulation and cognition. Dalam M. D. Robinson, E. R. Watkins, E. H. Jones (Eds.), Handbook of cognition and emotion. New York: The Guilford Press. 
Thompson, L.Y., Snyder, C.R., Hoffman, L., Michael, S.T., Rasmussen, H.N., Billings, L.S., Heinze, L., Neufeld, J.E., Shorey, H.S., Roberts, J.C., \& Robert, D.E., (2005). Dispositional forgiveness of self, other, and situation. Journal of Personality, 73 (2), 313-359.

Umberson, D., Williams, K., Powers, D. A., Liu, H., \& Needham, B. (2005). Stress in childhood and adulthood: Effects on marital quality over time. Journal of Marriage and Family, 67, 1332-1347.

Vassi, I., Veltsista, A., \& Bakoula, C. (2009). Parenting practices and child mental health outcomes. Dalam P. H. Krause \& T. M. Dailey (Eds.), Handbook of parenting styles, stresses, and strategies. New York: Nova Science Publishers, Inc.
Västfjäll, D., \& Slovic, P. (2013). Cognition and emotion in judgement and decision making. Dalam M. D. Robinson, E. R. Watkins, E. H. Jones (Eds.), Handbook of cognition and emotion. New York: The Guilford Press.

Worthington, E.L., \& Scherer, M. (2004). Forgiveness is an emotion-focused coping strategy that can reduce health risks and promote health resilience: Theory, review, and hypotheses. Psychology and Health, 19 (3), 385-405.

Yiend, J., Barnicot, K., \& Koster, E. H. W. (2013). Attention and emotion. Dalam M. D. Robinson, E. R. Watkins, E. H. Jones (Eds.), Handbook of cognition and emotion. New York: The Guilford Press. 